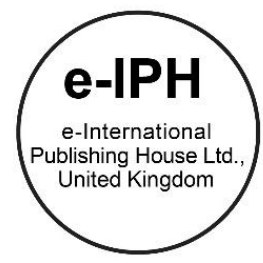

\title{
Reading Urban Ingredients: \\ What characterizes eating out space in urban spatial context
}

\author{
Olga Nauli Komala, Evawani Ellisa, Yandi Andri Yatmo \\ Department of Architecture, \\ University of Indonesia, Kampus Baru UI, Depok, 16424, Indonesia \\ nauli.olga@gmail.com \\ +62 8561845852:
}

\begin{abstract}
This paper explores eating out space by reading urban ingredients. The aim is to understand what characterizes eating out space in urban context. We conducted fieldwork and observing the physical and non-physical elements related to eating out space at Pancoran, Petak Sembilan, Gloria and Kalimati Alleys, Jakarta. Urban food legend, religion, community, supporting activities and traditional market are urban ingredients which characterize eating out space at Pancoran and give basic ideas of placemaking related to food. In this case, the community has a significant role in keeping or changing the elements of urban ingredients.
\end{abstract}

Keywords: community; food-related space; urban ingredients; culture

eISSN: 2398-4287@ 2017. The Authors. Published for AMER ABRA by e-International Publishing House, Ltd., UK. This is an open access article under the CC BYNCND license (http://creativecommons.org/licenses/by-nc-nd/4.0/). Peer-review under responsibility of AMER (Association of Malaysian Environment-Behaviour Researchers), ABRA (Association of Behavioural Researchers on Asians) and cE-Bs (Centre for Environment-Behaviour Studies), Faculty of Architecture, Planning \& Surveying, Universiti Teknologi MARA, Malaysia.

https://doi.org/10.21834/e-bpj.v2i6.984

\subsection{Introduction}

Food and eating space become the vital symbol of urban life (Bell and Valentine in Jayne, 2006), cultural barometer and city landmark (Jayne, 2006). Food fills the urban space in the form of food production; food processing and food discard (Twiss, 2012). It also represents the culture (Muhammad, Zahari Shariff, and Abdullah, 2016). Besides, food has political - economic value (Mintz in Mintz and Du Bois, 2002); the symbolic value (Gumerman IV, 1997; Munn in Mintz and Du Bois, 2002); and memory value in the form of social construction (Sutton in Mintz and Du Bois, 2002). Food becomes an integral component of culture, a midpoint of cultural identity and belongs to distinct society (Nor et al. 2012). Production and consumption process make the food has complex social meaning (Alvarez in Torres and de la Fuente, 2012). As human civilization developed, more people are involved in provisioning food. Thus the system is more complicated than before. Furthermore, spaces - created to food follows this complexity. Food is not only consumed in the domestic area, but also in public domain.

In this research, we focus on food consumption in the form of eating out space. The objective of this paper is to read urban ingredients by exploring what characterizes eating out space in urban spatial context. Eating out activities becomes the essential aspect in giving the meaning of eating out process. The pattern of urban ingredients, as the root of the place, can be the necessary things to develop and promote the idea of place making related to food.

\subsection{Literature Review}

The issues related to food have explored in many ways. They are the relationship of food and the identity (Ismail, Muhammad, Yusoff, Shariff, 2016; Nor, et al., 2012); environmental setting (Wardono, Hibino, and Koyama, 2017); and hygiene (Teh, Hamid, Asmawi, Nor,

eISSN: 2398-4287@ 2017. The Authors. Published for AMER ABRA by e-International Publishing House, Ltd., UK. This is an open access article under the CC BYNCND license (http://creativecommons.org/licenses/by-nc-nd/4.0/). Peer-review under responsibility of AMER (Association of Malaysian Environment-Behaviour Researchers), ABRA (Association of Behavioural Researchers on Asians) and cE-Bs (Centre for Environment-Behaviour Studies), Faculty of Architecture, Planning \& Surveying, Universiti Teknologi MARA, Malaysia.

https://doi.org/10.21834/e-bpj.v2i6.984 
2016). Mintz \& Du Bois (2002) studied food in the form of social construction of society. Some of them also explored food and tourism (Stringfellow et al., 2013); food and psychological factors (Muhammad, Ibrahim, Ahmad, Hanan, 2016). There are also studies about eating activities and memorabilia (Wardono, Hibino, Koyama, 2017); eating as cultural expression (Stringfellow et al., 2013); eating and consumer behavior or emotion (Ariffin, Bibon, and Abdullah, 2017; Astuti \& Hanan, 2016). Some researchers explored the relationship of traditional food and group identity and authenticity (Muhammad, Zahari Shariff, and Abdullah, 2016); self-identification of the customer (Rahadi, 2017); the influence of urban food system in urban space (Lim, 2014). There are also studies about the relationship between food and religious or cultural ceremonial (Muhammad et al., 2013; Sharif et al.,2013). It refers to how food forms social meaning (Douglas in Twiss, 2012) and becomes something that unifies or separates community (Mintz and Du Bois, 2002). How people prepare, serve and consume food mark the distinction between people (Muhammad, Zahari Shariff, and Abdullah, 2016). Earlier generations in every ethnic group also created their food culture by using the natural resources or any edible things (Muhammad et al., 2013). Therefore, how people deal with food is different regarding its context. Some researchers view the important role of food in reflecting city image and the everyday life of its community (Kim and Ellis, 2014).

Previous researchers have also explored how eating activities fill urban space. The agglomeration of eating space influences the quality of life, social characteristic and demographic aspect (Neal, 2006). The place plays a role in giving importance to eating habits (Johnston, Rodney, and Szabo, 2012). How food relates to place can be found in the concept of terroir, which refers to the making of taste by the production process of local agricultural product (Sutton, 2010). De St. Maurice (2012) also sees the taste of place concept that is socially produced and differentiates it from others.

\subsection{The Issue of this Research}

Concerning to the relation of eating out and space, some researchers have explored how the environment influences the behavior of the customers concerning the elements of space (Wardono, Hibino, Koyama, 2017; Voon. 2017). Food also affects the transformation of urban space, which relates to some variables, such as social, political aspect and culture (Lim, 2014). On the other hand, previous researchers have not revealed how urban elements characterize eating out activities, as well as eating out space in urban spatial context. The changing of technology, culture, and lifestyle are followed by the complexity of space related to food so that the space for producing and consuming food becomes more diverse than before. The main issue of this paper is the relation of urban elements and eating out space. We tried to read urban ingredients to find what characterize eating out space in urban spatial context, which becomes more complex and more diverse than before.

\subsection{The Process of Reading Urban Ingredients in Urban Context}

The process of reading includes the readers and the text. In this case, the researchers are the readers and the study area is the text. The text refers to "a message put together regarding specific code," which bears the meaning in the particular context (Danesi and Perron, 1999). There is a relationship between text and code. An attempt to use the code as means of deciphering social space reduce it to the status of a message, and the inhabiting of it, to the process of reading (Lefebvre, 1991). According to Danesi and Perron (1999), a code is a structural system and has relation to sign, text and context. Furthermore, the term context refers to "the real - world conditions - physical, psychological, social, etc. - that influence, shape and even determine how the making of a text or what a text means" (Danesi and Perron, 1999). Lefebvre (1991) argues that texts refer neither other texts nor their contexts, rather to nontexts. According to Lefebvre (1991), a spatial work has different complexity from a text, which does not apply to text but to texture. In this case, it is made up of usually rather large space covered by networks or webs. The texture of space affords opportunities to social acts with no particular link to it and spatial practice that it does indeed determine, namely its collective and individual use (Lefebvre, 1991). Every space has its language, and then every discourse says something about space (Lefebvre, 1991).

At the end of the reading process, we are able to recognize the elements that characterize eating out space. The character is determined by how things are and gives our investigation a basis in the concrete phenomena of our everyday lifeworld (Schultz, 1991). According to Schultz (1991), we must recognize these elements to identify the place, such as the phenomena, the structure and the spirit of the place, natural place, and human-made place or genius loci. The process of reading an urban area refers to finding the specific elements which emerge from the area and differs eating out space. Since the process of reading could be applied only to spaces already produced it could not help us to understand the actual production of space (Lefebvre, 1991). Nevertheless, this research does not mean that we want to know how the eating out space is produced, which becomes the limitation of our research.

Analogous to the process of cooking, we use the term of urban ingredients to refer to the elements of urban space which connects to food or as a part of the urban food system in this research. They also include all supporting elements which give characteristic to eating out activities and space, although they do not belong to the urban food system. We explore the activities and spaces related to food and eating out activities in the area of our case study as a part of our reading process.

Diagram 1 shows the process of reading and finding urban ingredients, which needs the ability to recognize urban elements. We can read the physical elements of urban space from the existence of natural context, street system, plot system and building system (Oliveira, 2016). They give influence on creating the identity of place. The physical (functional) components, the meaning and the association between people and places and the emotional aspects of environmental experiences determine the identity of place (Ujang, 2017). All these physical elements are produced in particular context so that understanding the context becomes the important thing to understand an urban area. However, knowing the elements is not enough to know an urban area. Therefore, we must understand the non-physical ones which attach and give meanings to the physical elements. 


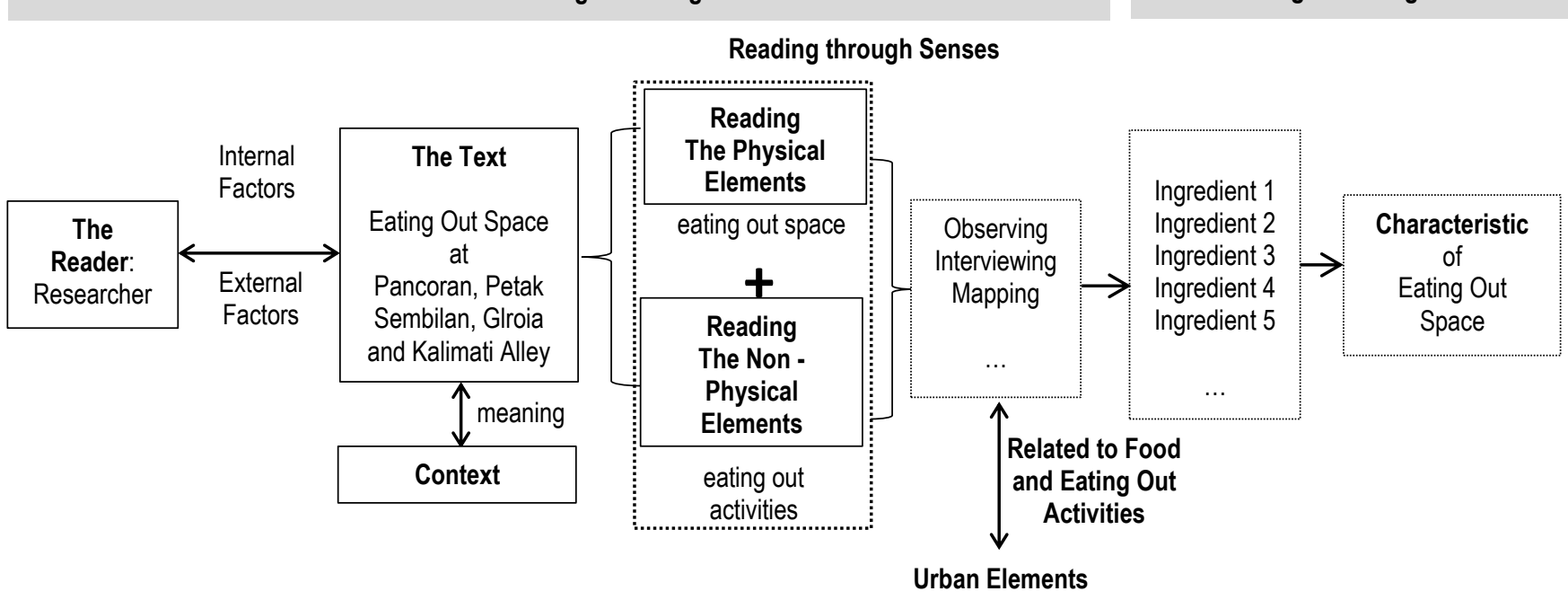

Diagram 1. The process of reading and finding urban ingredients

\subsection{Eating Out Space in Urban Context}

The complexity of eating out space follows the development of civilization. More types of eating out space have emerged not only to fulfill basic needs but also to reflect identity or get new experiences. The trend of eating out activities are triggered by long working hours, which causes lack of time or energy to prepare dinner, and the emerging trends such as higher income and population specifically in the urban area (Basri et al., 2016). Eating space is a part of consuming space, which does not only cover the activities inside but also becomes consumption product (Astuti and Hanan, 2016). It creates emotional ties of the customers with their hometown, functions as poetic cultural symbols and influences sensory experience (Brown, 2003), which deals with tangible and intangible products (Ariffin, Bibon and Abdullah, 2017). Astuti and Hanan (2016) see the dining experience is the idea of food as a source of entertainment. Eating out spaces develop in many new concept, theme, service, and menu so that some new types of eating out space are modified to satisfy the customers (Yusof et al., 2016).

The eating out space in urban context has developed in many forms, from street food, restaurant, coffee shop/ Kopitiam, sidewalk café, mobile food vendors, food markets, festival scape, dining on the go, convenience food, and online shopping. They change by the changing of technology, culture, and lifestyle. Many variants of eating out space accommodate many meanings of eating out activities. In another case, the eating out activities in the form of the restaurant tends to make customer finding new eating experience and satisfaction (Wardono, Hibino, Koyama, 2017). The physical and social conditions of the consumer society strongly influence the choice of eating places (Urry in Astuti and Hanan, 2016). The eating out space tries to adjust the design to fulfill the need and character of the customers to create the suitable atmospheric elements, including style, lighting, and layout (Ariffin, Bibon, and Abdullah, 2017).

\subsection{Eating Out Activities in Urban Context}

The basic principles which describe the pattern of relationship between people and their activities in urban space can be classified as to assemble or disperse; to integrate or segregate; to invite or repel; and to open up or close in (Gehl, 2011). Eating out activities fills and triggers the activities in urban space, which tends to assemble, integrate with other activities, invite people and open up to attract more consumers. Eating out can relate to other activities and give meaning to space and activities. The eating out activities develops from basic survival thing as its denotative meaning to connotative and self - actualization. The development of the meaning of food and eating activities can relate to religion and ceremony (Telfer, 1996), social status, occupation, gender, age (Gumerman IV, 1997), ceremony and social event (Lim, 2004). Eating activities have a symbolic meaning which relates to its surrounding environment, while food can be performative medium (Horwitz and Singley, 2004). Furthermore, the changes in eating activity have encouraged the development of consuming food as a cultural industry (Astuti and Hanan, 2016). Eating is also a combination and intersection of food and culture (Muhammad, Zahari, Shariff, Abdullah, 2016). Now, eating places are not only places for eating but also places with many functions, such as for socialization, waiting, hanging out, working and discussing (Astuti and Hanan, 2016). Human interaction can enhance psychological benefits and human wellness (Omar, 2017). Specific customers also have certain considerations regarding their eating environment (Voon, 2017). It means that the eating out activities can relate to the type of the consumers. Astuti and Hanan (2016) see that consuming food is not only a basic need but also a need for social function because consuming food represents a symbolic system. 


\subsection{Research Method}

Since the issue of eating out activity depends on the time and place, we selected specific area as the case study. Jakarta has the vast amount of eating out spaces, from street food to high-class restaurants. They are influenced not only by local cultures but also by foreign and global cultures. We can classify some eating out spaces in Jakarta. They are eating out space which provides food for everyday need; collective eating out space which has particular character; eating out space which locates in POPs (Privately Owned Public Space); eating out as supporting facilities; and temporary eating out space, such as food festival. In this research, we focus on collective eating out space which has distinct character as our case study. The unit analysis of this research is all eating out spaces which have relation to urban space, within the study area. In this case, the types of eating out spaces may vary, but all of them have the connection to urban space. To know and explore the urban ingredients, we conduct the field work at four strips as our case study, namely Pancoran, Petak Sembilan, Gloria Alley and Kalimati Alley.

Figure 2 shows the big scheme of our research. The first step is finding the urban ingredients within the study area. It becomes the position of this study. Further research has shown that in the next step it includes the exploration of many derivative variants of each urban ingredient. Every variant has many variant's combinations. Through exploring the variants of the derivative and the mix of urban ingredients, we will find out the root and the pattern of urban elements related to food. This finding is useful in developing place making based on the essential elements of the community.
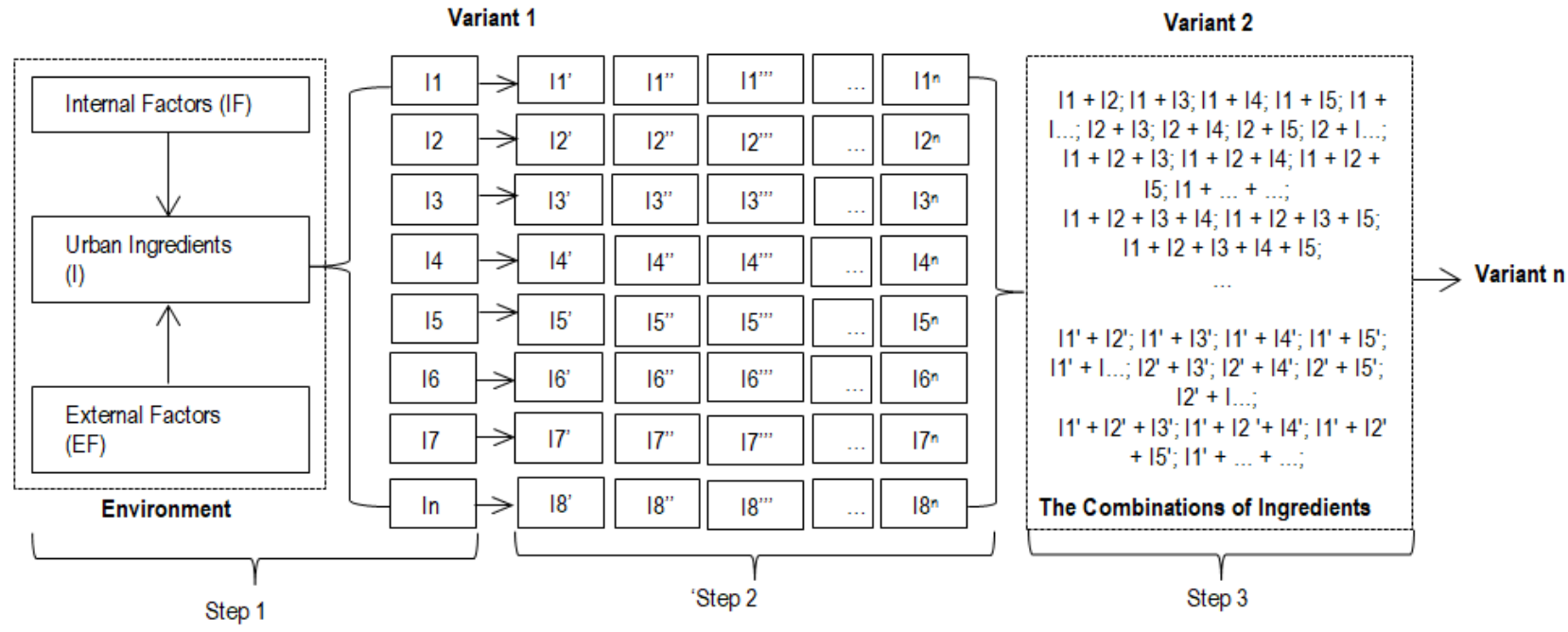

Diagram 2. The big scheme of our research

The Table 1 below shows the relation of the information, data type, source, data collection technique and data analysis procedure in our research.

Table 1. Research Method: The relation of information, data type, data source, data collection technique and data analysis procedure

Reading Urban Ingredients

Case Study: Pancoran, Petak Sembilan, Gloria and Kalimati Alleys, West Jakarta

Unit of Analysis: Eating out spaces which have relation to urban space, both in private and public domain.

Observation Time: Linear Time: whole day observation, including weekend and weekdays ;

Cyclic Time: past and present time

Researchers as participant/ research role concealed

\begin{tabular}{|c|c|c|c|c|}
\hline Information & Data Type & Data Source & Data Collection Technique & Data Analysis Procedure \\
\hline \multirow[t]{2}{*}{$\begin{array}{l}\text { Physical } \\
\text { Elements }\end{array}$} & $\begin{array}{l}\text { Physical } \\
\text { elements } \\
\text { related to food } \\
\text { and eating out } \\
\text { space }\end{array}$ & $\begin{array}{l}\text { Eating out environment at } \\
\text { Pancoran, Petak Sembilan, } \\
\text { Gloria and Kalimati Alleys, } \\
\text { which has the connection to } \\
\text { urban space }\end{array}$ & $\begin{array}{l}\text { Observation: } \\
\text { Record all physical elements related to } \\
\text { food and eating out activities by sketches, } \\
\text { field notes, video, photos, and mapping. }\end{array}$ & \multirow{2}{*}{$\begin{array}{l}\text { The Tool of Analysis: } \\
\text { data maps, photo montage, Figure, video, } \\
\text { three-dimensional model } \\
\text { Reading Data and Memoing } \\
\text { - Explore and read general physical elements } \\
\text { based on natural context, street system, plot } \\
\text { system, and building system (Oliveira, 2016). } \\
\text { - Eating out activity is analyzed based on the } \\
\text { characters of activities in urban space: to } \\
\text { assemble or disperse; to integrate or } \\
\text { segregate; to invite or repel; and to open up } \\
\text { or close in (Gehl, 2011). }\end{array}$} \\
\hline & $\begin{array}{l}\text { The types of } \\
\text { eating out } \\
\text { spaces }\end{array}$ & $\begin{array}{l}\text { Eating out spaces which } \\
\text { locate on: } \\
\text { public space; the boundary } \\
\text { between public and private } \\
\text { space; and private space } \\
\text { which have relation to public } \\
\text { space }\end{array}$ & $\begin{array}{l}\text { Observation } \\
\text { Classify eating out spaces based on the } \\
\text { type of space permanency; the type of } \\
\text { food; consumption space; and the location } \\
\text { of eating out space. } \\
\text { Record all eating out spaces by sketches, } \\
\text { field notes, video, photos, mapping and } \\
\text { three-dimensional models. }\end{array}$ & \\
\hline
\end{tabular}




\begin{tabular}{|c|c|c|c|c|}
\hline & $\begin{array}{l}\text { The actors/ } \\
\text { community } \\
\text { (food sellers } \\
\text { and buyers, } \\
\text { and residents) }\end{array}$ & $\begin{array}{l}\text { People who live, work and } \\
\text { visit the study area }\end{array}$ & $\begin{array}{l}\text { Observation } \\
\text { Observe the people who engage in } \\
\text { activities related to food, as well as their } \\
\text { character in the study area. } \\
\text { Record the data by making field notes, } \\
\text { photos, video and audio recording } \\
\text { Interview with snowball sampling } \\
\text { Open-ended interview related to the study } \\
\text { area as well as food and eating out } \\
\text { activities }\end{array}$ & $\begin{array}{l}\text { Describing } \\
\text { Describe the observation of physical } \\
\text { elements and activities related to food and } \\
\text { eating out activities, using maps and Figure. } \\
\text { Classifying } \\
\text { Classifying the activities and the space } \\
\text { related to eating out activities based on its } \\
\text { pattern. } \\
\text { Interpreting }\end{array}$ \\
\hline \multirow[t]{2}{*}{$\begin{array}{l}\text { Non - Physical } \\
\text { Elements }\end{array}$} & $\begin{array}{l}\text { Activities } \\
\text { related to food } \\
\text { and eating out } \\
\text { activities }\end{array}$ & $\begin{array}{l}\text { Eating out environment at } \\
\text { Pancoran, Petak Sembilan, } \\
\text { Gloria and Kalimati Alleys }\end{array}$ & $\begin{array}{l}\text { Observation } \\
\text { Record all the activities related to food } \\
\text { and eating out activities by field notes, } \\
\text { photos, video, sketches and mapping }\end{array}$ & $\begin{array}{l}\text { Interpreting the data based on theory, the } \\
\text { analysis, and concluding. } \\
\text { Representing, visualizing } \\
\text { We represent and visualize the result of the }\end{array}$ \\
\hline & $\begin{array}{l}\text { History related } \\
\text { to food and } \\
\text { eating activities }\end{array}$ & $\begin{array}{l}\text { Written and oral historical } \\
\text { information }\end{array}$ & $\begin{array}{l}\text { Literature and Internet } \\
\text { Record all information about the food of } \\
\text { our case study } \\
\text { Interview with snowball sampling }\end{array}$ & $\begin{array}{l}\text { analysis of eating out space in the form of } \\
\text { mapping, Figure, table and text (descriptive). }\end{array}$ \\
\hline
\end{tabular}

\subsection{Case Study: Pancoran, Petak Sembilan, Gloria and Kalimati Alleys, Jakarta}

Pancoran, Petak Sembilan, Gloria and Kalimati Alleys are part of Glodok district. They are also known as Jakarta's Chinatown and one of culinary destination, where we can see how Chinese and local culture mix and give influence to each other in many aspects. In this case, the complexity of urban eating space blends with the uniqueness and the changes of community. Initially, this area was developed by the Dutch government to relocate Chinese residents from Batavia to Linkwatiersgracht or Glodok after the riot in 1740. Pancoran district played a role in supplying drinking water in Batavia. Nowadays, commercial activities become dominant along Jalan Pancoran. Although the street is still active, the activities related to food are not the primary activity of Jalan Pancoran. Spaces related to food move to the second layer of the street, which takes place at Kalimati and Gloria Alley and Petak Sembilan.

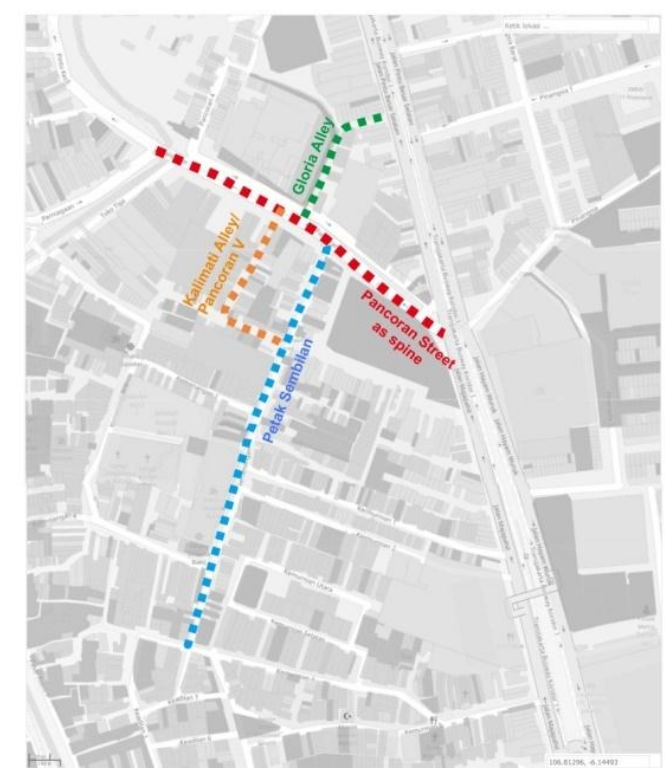

Figure 1. The map of Pancoran, Petak Sembilan, Gloria and Kalimati Alleys Source: http://www.bpn.go.id/

\subsection{Finding and Discussion}

Regarding urban ingredients in our case study, some considerations in reading eating out activities are:

a. Physical elements include the most culinary places, both in the past and the present time as well as strong relation to the urban food system, regarding food production, food distribution, and food consumption.

b. Non-physical elements include the supporting activities surrounding eating out spaces; sensory experience regarding eating out activities; community; and the type of activities related to food and eating out activities.

Table 2 shows the mapping of some physical elements at Jalan Pancoran, Petak Sembilan, Gloria and Kalimati Alleys. 


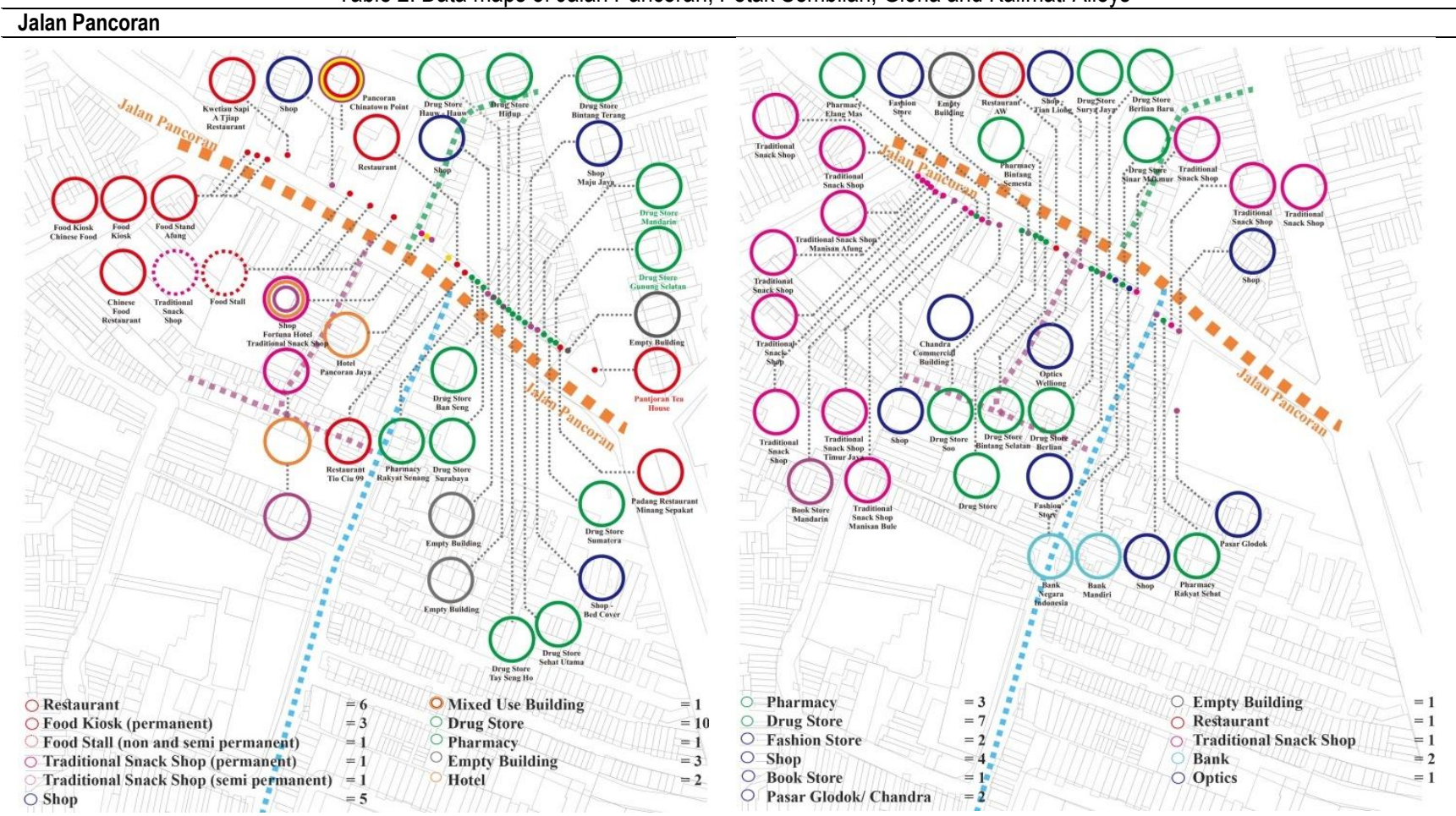

Figure 2(a) The right side; and (b). The left side of Jalan Pancoran

Jalan Pancoran is dominated by the existence of drug stores and traditional snack shops and supported by commercial activities and food vendors.
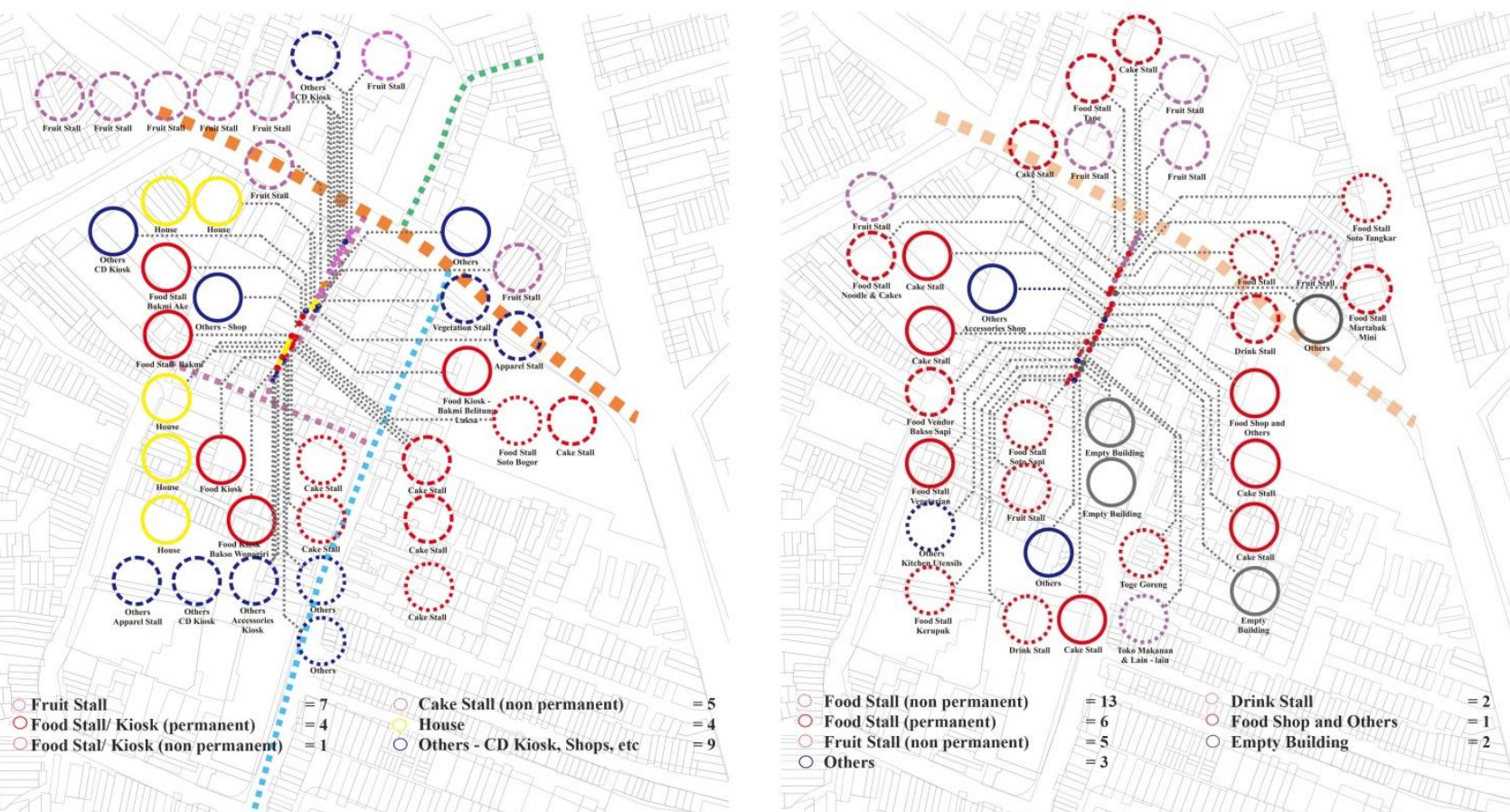

Figure 3(a) The right side; and (b). The left side of Kalimati Alley

Kalimati Alley is dominated by food kiosks, housings, street vendors and other kiosks. Some fruit stalls can be found in the area which connects to Jalan Pancoran. 


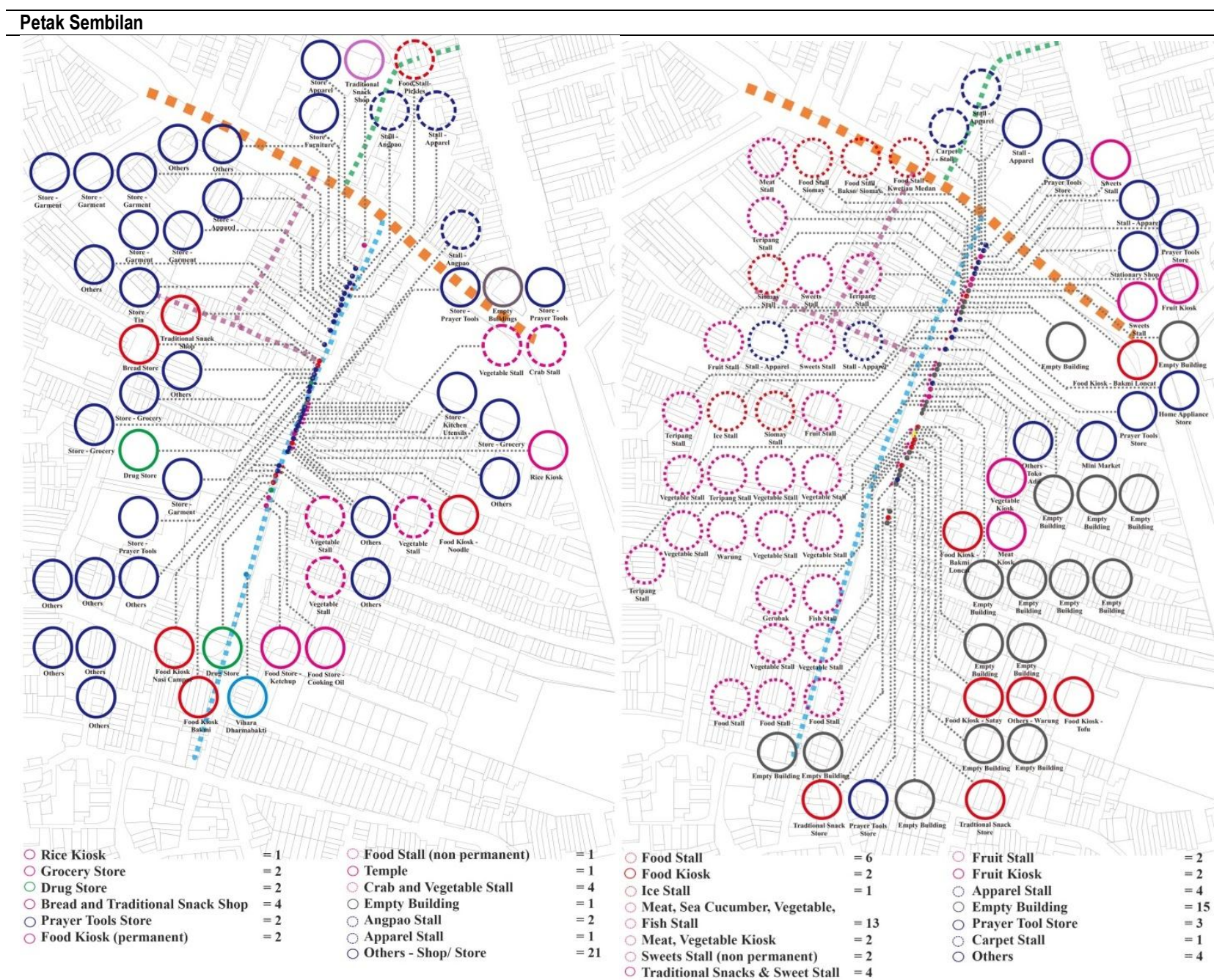

Figure 4(a) The right side; and (b). The left side of Petak Sembilan

Petak Sembilan is dominated by the kiosks or stalls related to the activities of traditional market. It becomes a place for the consumption and distribution of foodstuff. The existence of Chinese prayer tools store and the temple (Vihara Dharmabakti) show the domination of Chinese culture in this area.

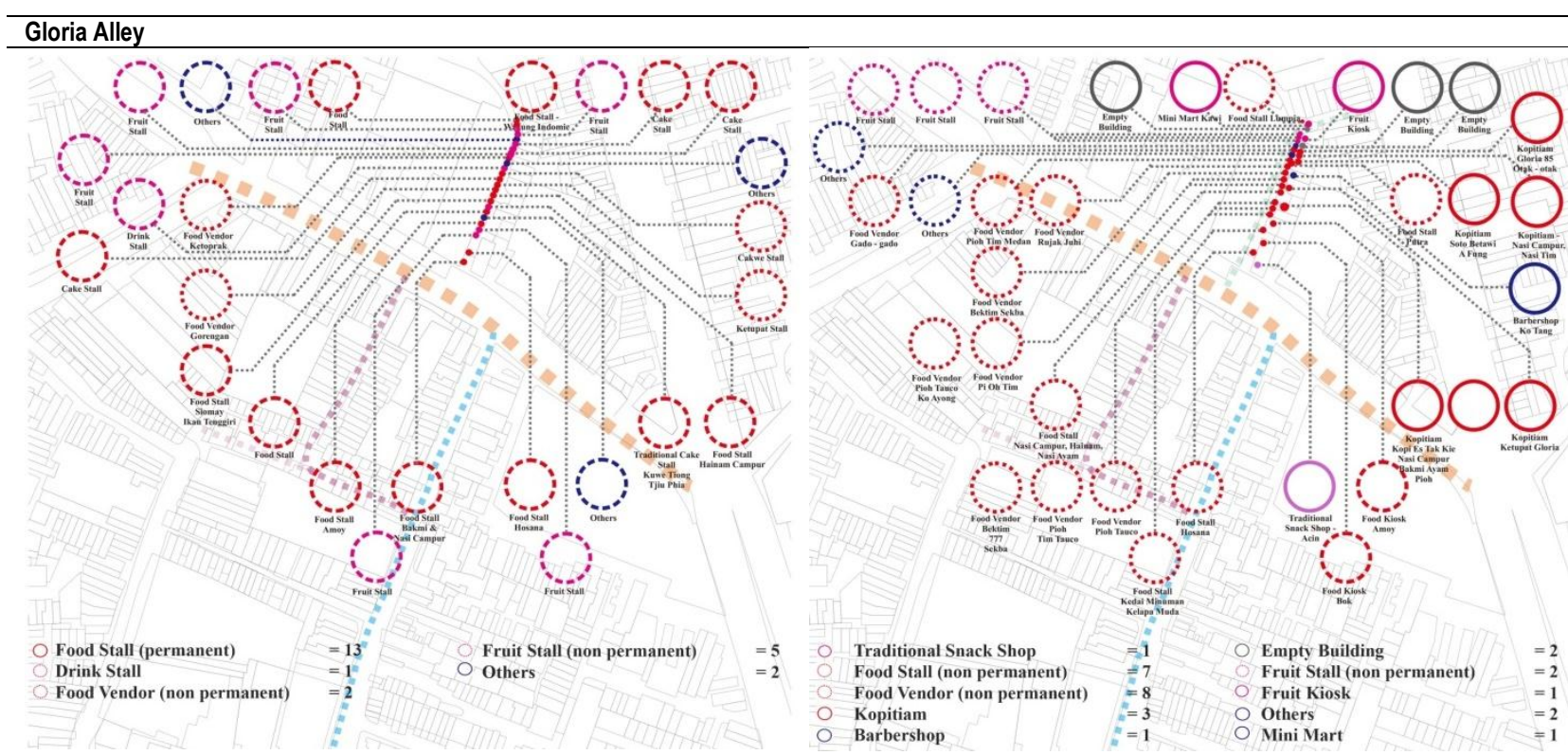

Figure 5(a) The right side; and (b). The left side of Gloria Alley 
Table 3 shows the physical and non - physical elements of each part of our case study area, which have relation to the urban food system. Identifying and grouping each urban element according to its relationship with food and eating activities can be seen in the mapping below.

Table 3. Physical elements, non-physical elements and urban ingredients of Jalan Pancoran, Petak Sembilan, Gloria and Kalimati Alleys

\begin{tabular}{|c|c|c|c|}
\hline & Physical Elements & Non - Physical Elements & Urban Ingredients \\
\hline $\begin{array}{l}\text { Jalan } \\
\text { Pancoran }\end{array}$ & $\begin{array}{l}\text { - Old famous Chinese restaurants from Colonial Era } \\
\text { - Strip as the main layer with some alleys at the } \\
\text { second layer } \\
\text { - Strip with many shops, traditional drugstores, street } \\
\text { vendors and traditional snack shops } \\
\text { - Old buildings at the two sides of the strip } \\
\text { - Commercial arcade } \\
\text { - Space-related to food and eating out activities in } \\
\text { the form of street vendors and restaurants }\end{array}$ & $\begin{array}{l}\text { - The domination of Chinese community which } \\
\text { mixes with the local community } \\
\text { - The changing of supporting activities related } \\
\text { to food based on time of events, from clothes } \\
\text { to food seller in the afternoon }\end{array}$ & $\begin{array}{ll} & \text { Urban food legend } \\
\text { - } & \text { Community } \\
\text { - } & \text { Supporting activities }\end{array}$ \\
\hline
\end{tabular}

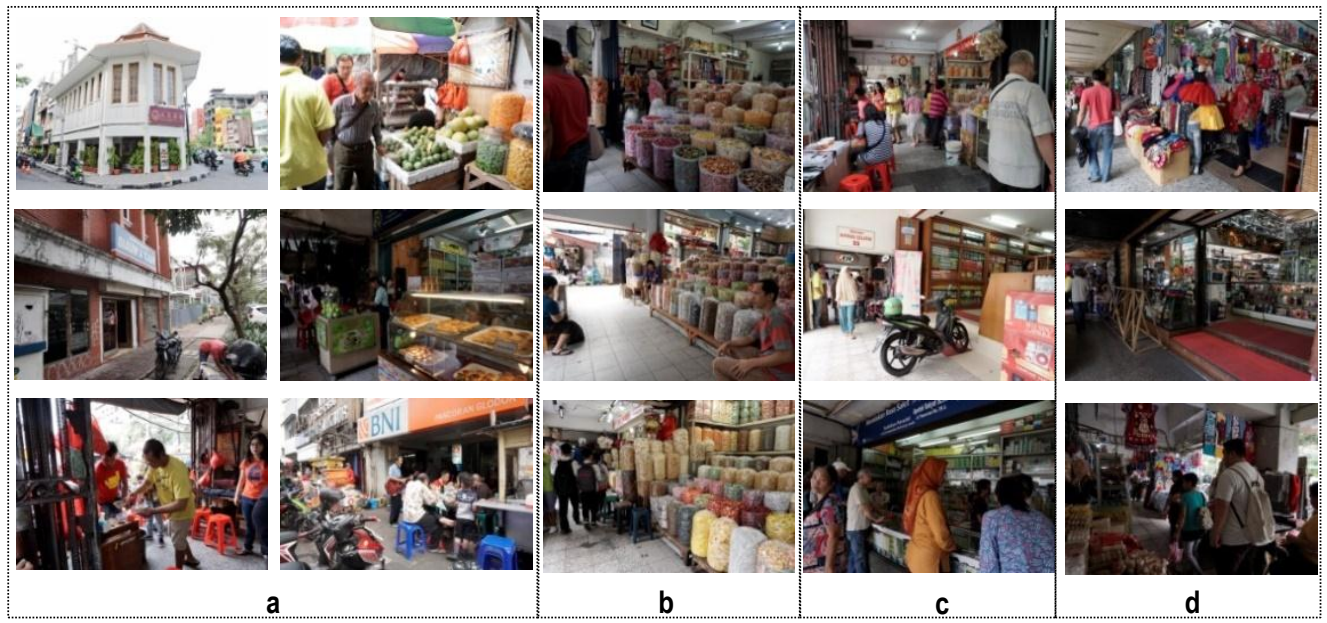

Figure 6(a). Space-related to food consumption; (b).Traditional snack shops; (c).Traditional drugstore; (d). Commercial arcade and supporting activities

Source: author, 2017

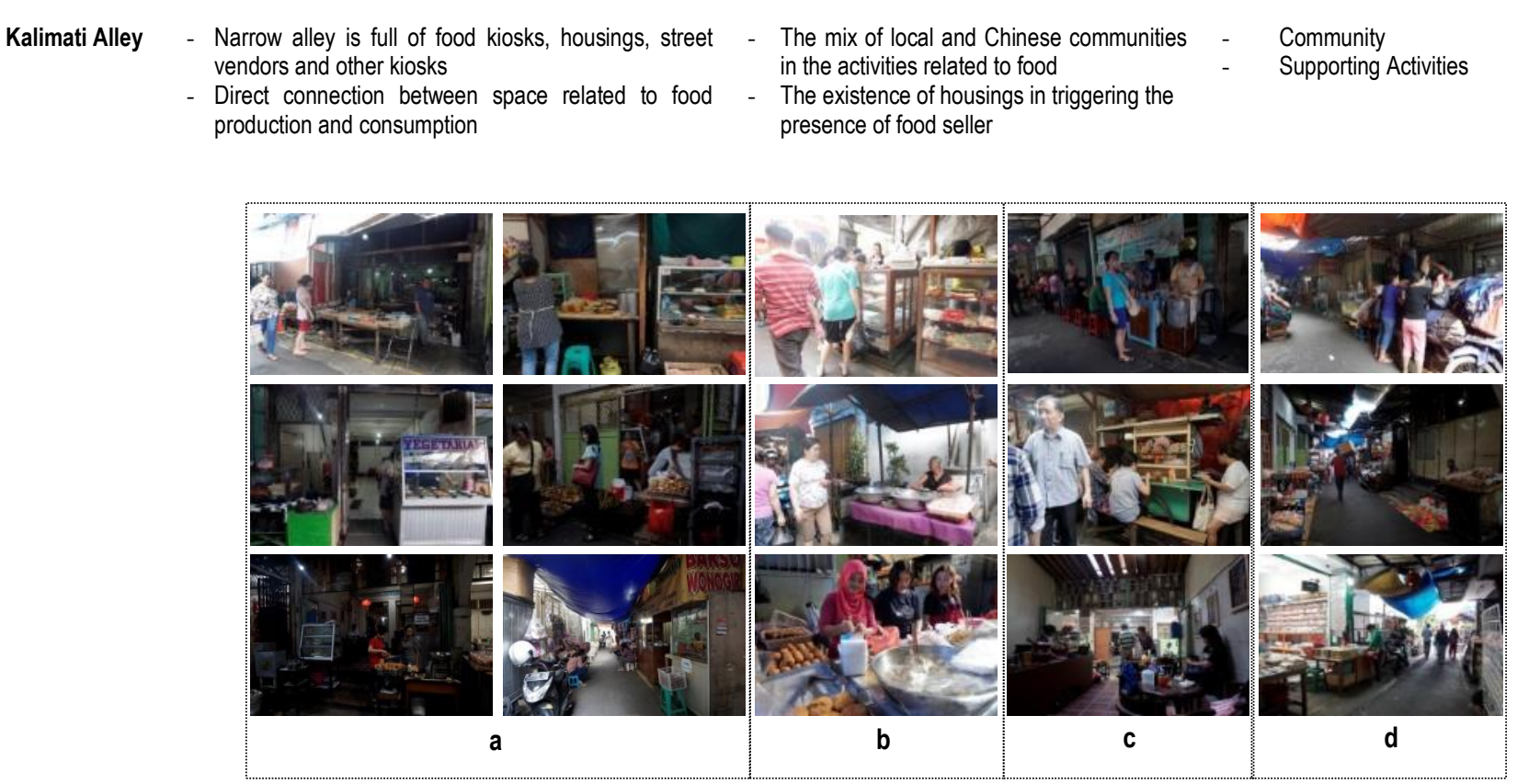

Figure 7(a). The direct connection between space related to food production and food consumption (b).Food kiosks; (c). Space-related to food consumption; (d). Supporting activities

Source: author, 2017 
Petak Sembilan
Traditional market with many street vendors and other temporal spaces

- The existence of temples around the area

- The consumption and distribution of foodstuff, from meat, vegetables, spices, etc.
The domination of Chinese culture and - Traditional market community which mix with the local culture - Religion

- Community
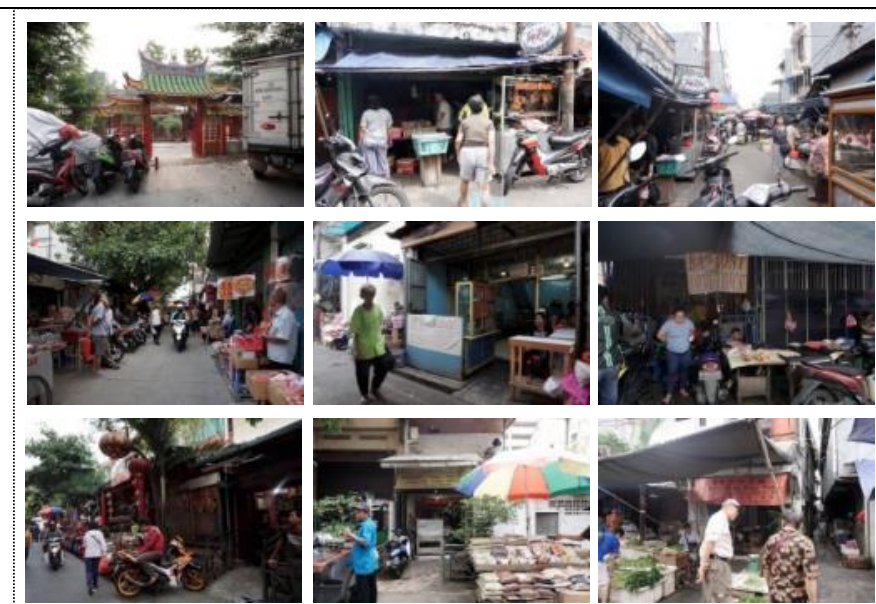

a
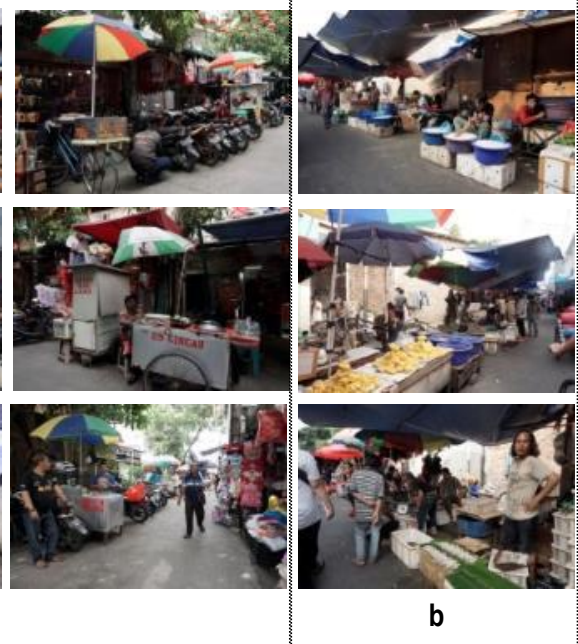

Figure 8(a). Temples and traditional market; (b). Space and activities related to food distribution Source: author, 2017
Narrow alley with full of food kiosks
Direct connection between space
related to food production and consumption as well as urban space
- Space-related to food in the form of street vendor, permanent and temporal space
The most visited culinary spots in the form of Kopitiam, for almost a century

\section{The mix of local and Chinese communities in the activities related to food \\ - Urban Food Legend \\ The existence of other activities in supporting activities} related to eating out activities, such as selling fruit, and any other foodstuff
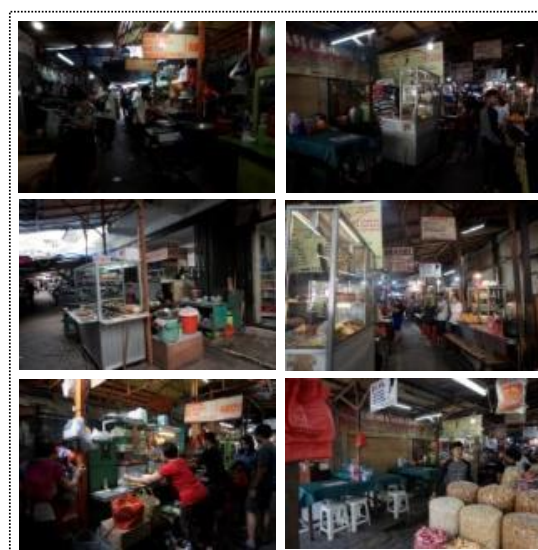
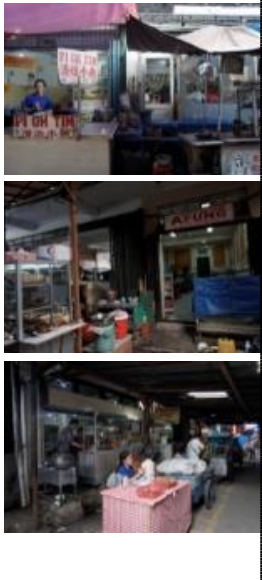
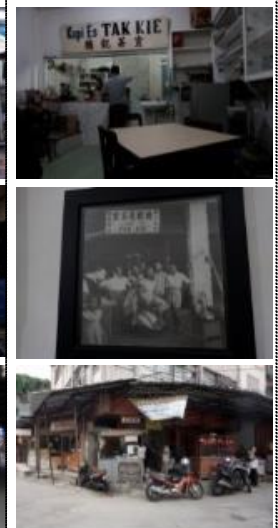

b

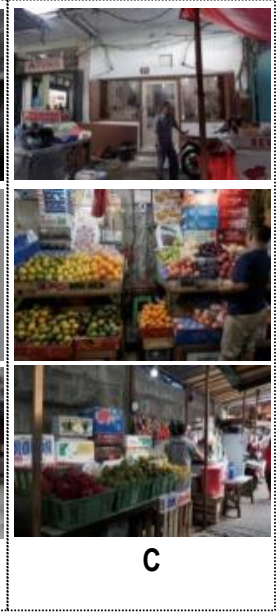

Figure 9(a). The direct connection between space related to food production and food consumption (b). Kopi Es Tak Kie and Kopitiam as urban food legend; (c). Supporting activities

Source: author, 2017

We can read urban ingredients as the root of urban area and community from the relationship between food and people. From table 2, we can see that there are five main urban ingredients which give influence in characterizing eating out space in the study area, namely: urban food legend, religion, community, supporting activities and traditional market. In this case, the issue about the relation between urban elements and eating out space is answered by exploring urban ingredients as the most influential factors which gives effect to the experience and the space of eating out. 


\subsection{Ingredients 1: Urban Food Legend (I.1)}

The term legend refers to "a story coming down from the past; a body of such stories; a popular myth of recent origin; a person or thing that inspires legends; and the subject of a legend" (https://www.merriam-webster.com/dictionary/legend). In this case, looking back at the history and food culture can define urban food legend. There are some food destinations as urban food legends in our case study, namely Jalan Pancoran (I.1.1); Pantjoran Tea House (I.1.2); traditional snack shop (I.1.3), Gloria Alley (I.1.4); and Kopi Es Tak Kie (I.1.5).

Jalan Pancoran (I.1.1) was formerly known as the culinary strip for most European elite community in Colonial Area. In the past, the street was dominated by Chinese restaurants. Some of the streets do not exist anymore, replaced by Chinese traditional drugstore, street vendors, and grocery store. It also includes Pantjoran Tea House (I.1.2), which formerly known as Ching Hwa Pharmacy in the colonial era. The tea house is chosen to replace the old building as pharmacy and continue the tradition of drinking tea in Chinese culture. The tradition of provisioning tea for all pedestrian by the owner of Chung Hwa pharmacy has been continuing by Pantjoran Tea House. Some traditional snack shops (I.1.3) have also become the landmark of this strip. The documentary photo shows that they have been there since 1955. Besides, Gloria alley (I.1.4) is full of food sellers, which becomes the landmark for this area as one of culinary destination for who search for Chinese food or new eating experience. Kopi Es Tak Kie kiosk, which has existed since a century ago, also becomes one of food destination for people who search for unique eating experience or recall the memory.

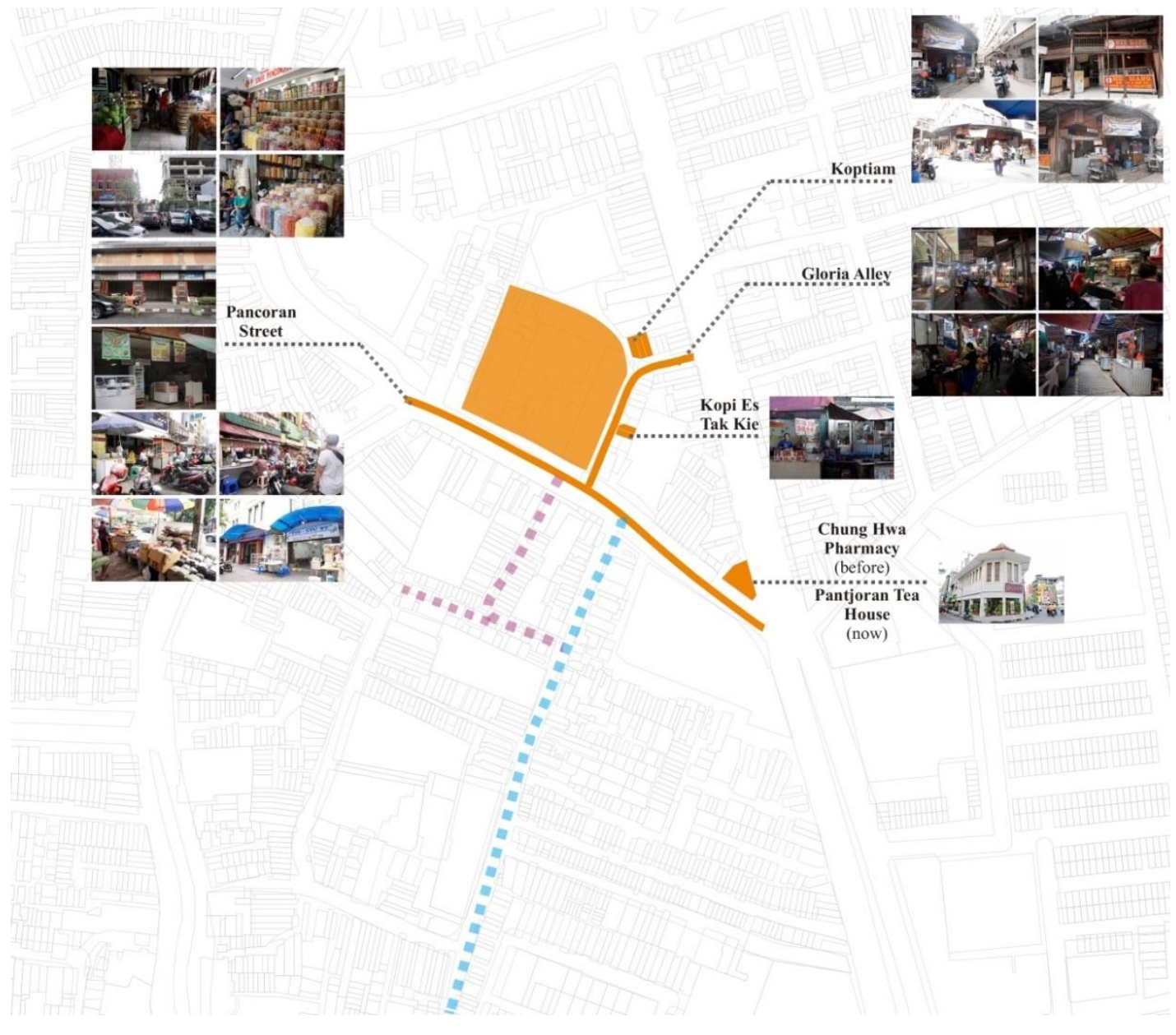

Figure 10. The mapping Ingredients 1 (I.1): Urban Food Legends Source: author, 2017

\subsection{Ingredients 2: Religion (1.2)}

This area is also well known for the numbers of Buddhist temples scattered around. Some of the temples are Vihara Dharmabakti as the biggest one (I.2.1); and Vihara Tao Se Bio (I.2.2). Although these temples are not part of the urban food system, they influence eating out activities through some aspects, which include the visitors of the temples, dominated by Chinese Indonesian, as well as the particular food in the special ceremony or holy day. The atmosphere of space with the distinct character of physical elements, activities, sight, smell, and sound also give the different sensation to the eating out space around the temple. There are also some religious buildings, such as the church (Santa Maria de Fatimah Church, I.2.3) and mosque around this area. Although the influence is 
not strong as the temples, they reflect the diversity of community because some of them are the consumers of eating out space in this area.

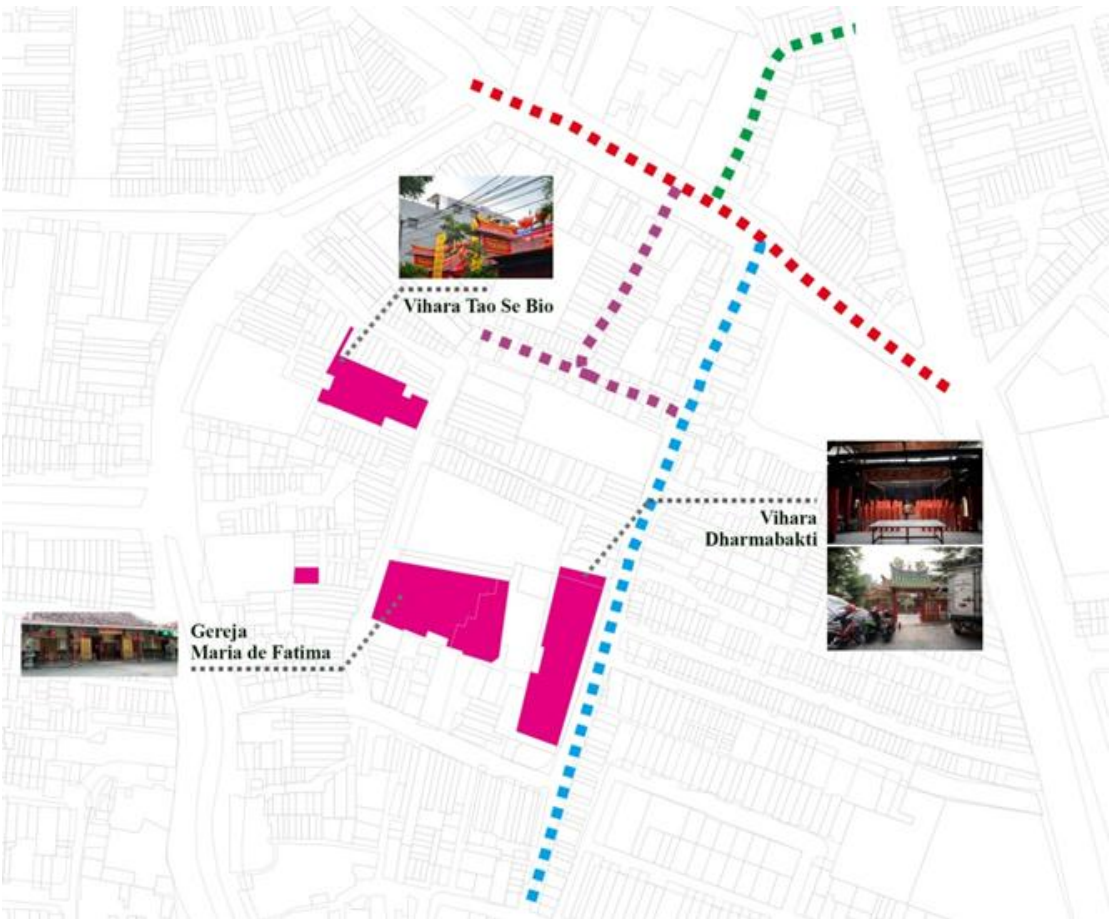

Figure 11. The mapping Ingredients 2 (I.2): Religion Source: author, 2017

\subsection{Ingredients 3: Community (I.3)}

There are three groups of people who have significant influence in our study area, who live, work and visit the area for specific purposes. Chinese Indonesian as majority group plays important roles in this area. They also mix with other ethnic in their daily activities in this area. The diversity of people brings varieties on how they use space including space related to food and eating activities. Initially, Chinese Indonesians (I.3.1) established the first eating out spaces in the form of restaurants, as part of the culinary strip at Jalan Pancoran. These restaurants become a culinary destination for the elite European community. Then, the second eating out spaces emerged in other to fulfill the needs of the local community (I.3.2), namely Kopi EsTak Kie and many local traditional food stalls, besides some traditional snack sellers and Chinese drugstore. In this case, the sellers and the consumer are not only Chinese Indonesians, but also local people.
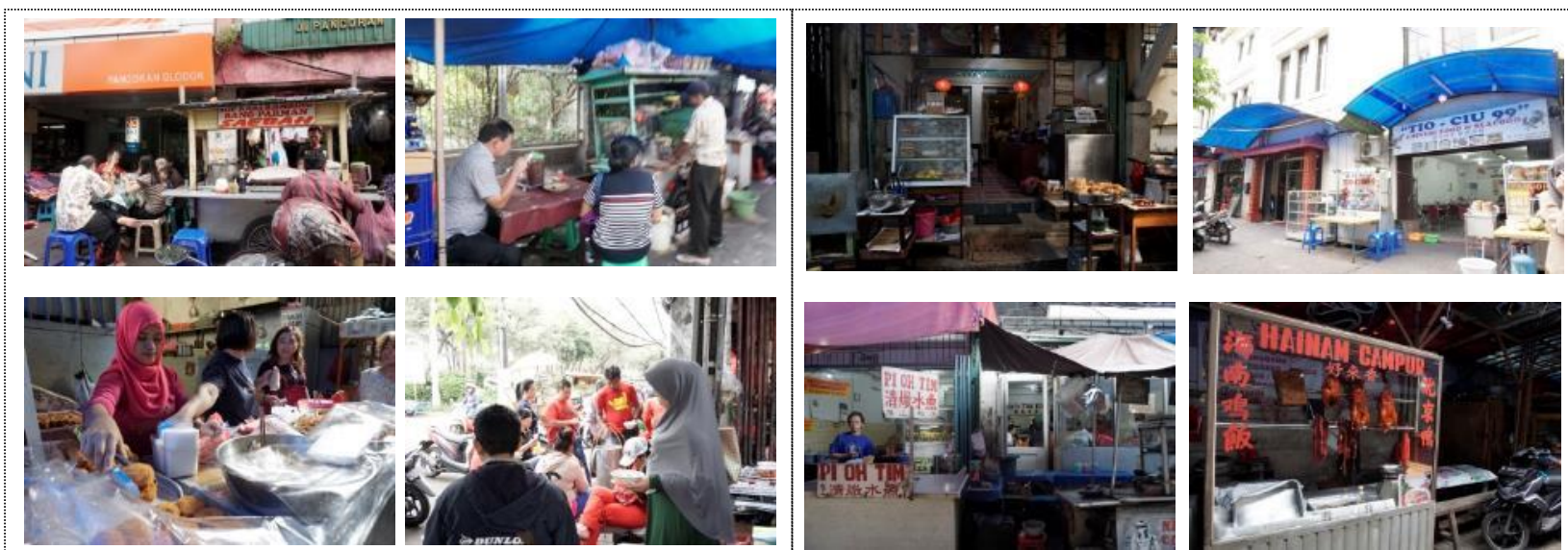

Figure 12. Ingredients 3 (I.3): Community - Local and Chinese Indonesian community give color in shaping the food culture (Source: author, 2017) 


\subsection{Ingredients 4: Supporting Activities (1.4)}

In Colonial era, Jalan Pancoran as the main layer was dominated by Chinese culinary spots. The changes had begun as the European moved out of this area after the independence of Indonesia. It has changed gradually from culinary destination to commercial strip (I.4.1) as the communities who give influences in this area have also changed. Nowadays, spaces related to food and eating out activities in this strip have transformed into temporary street vendors (I.4.2) which sell traditional Indonesian food.

The changes also happened at Kalimati alley as the second layer of Jalan Pancoran, which was initially dominated by housing. Around the 1980s, the local community of the alley started selling food to fulfill the basic needs of the residents. Now, we can find how this alley is bustling with activities related to food. Here eating is not only about fulfiling basic human needs but also about consuming memory and getting new eating experience. A similar situation also happens at Gloria Alley, where we can find many urban food legends, such as Kopi Es Tak Kie, Kopitiam, etc. In this case, consuming food is about recalling the past and celebrating the culture.
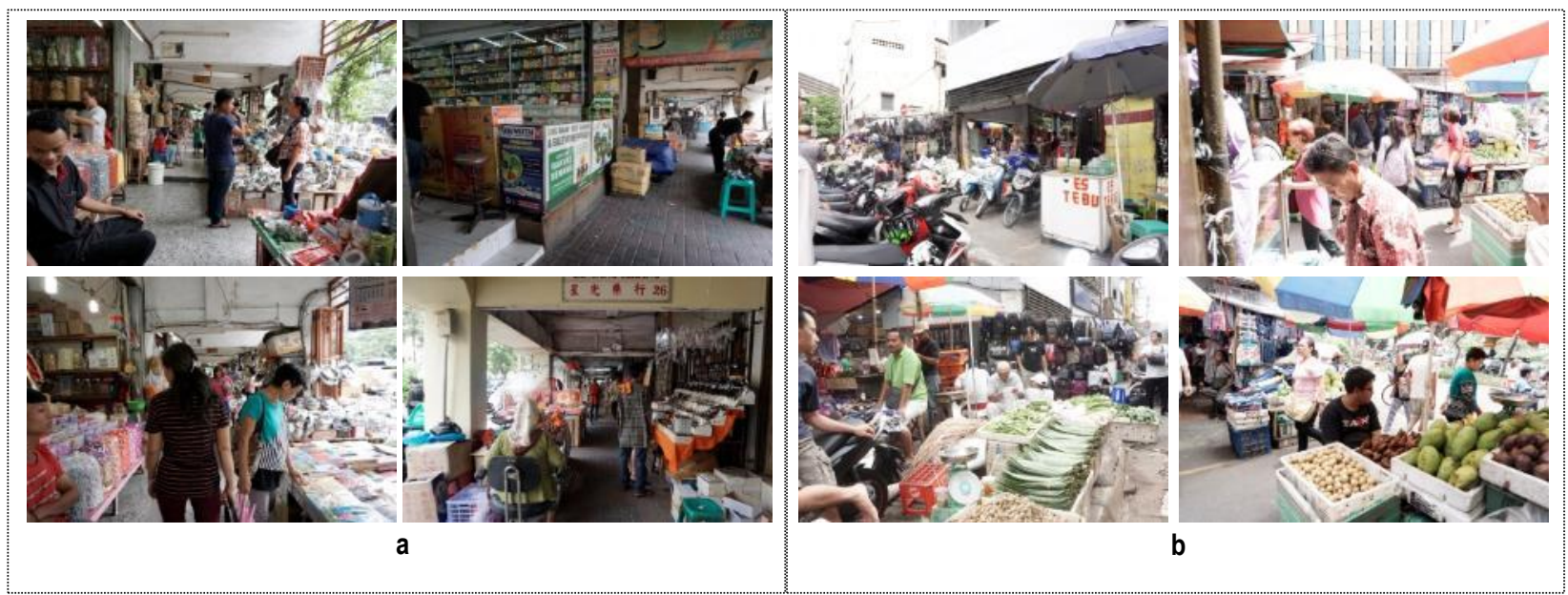

Figure 13. Ingredients 4 (I.4): Supporting activities (a). Commercial arcade; (b). Temporary street vendors (Source: author, 2017)

\subsection{Ingredients 5: Traditional Market (1.5)}

The existence of the traditional market, Petak Sembilan, becomes one of the landmarks in this area. The influence of Chinese culture makes the market becomes unique, which can be seen from the goods, the activities and the communities, as well as the physical appearance of some buildings inside. Considering to the urban food system, the traditional market of Petak Sembilan offers wide varieties of foodstuffs, from vegetables, meats to spices, not only for residents but also for visitors, specifically who search for something related to Chinese culture. Spaces related to food and eating out activities can be found in the form of temporary space and give vitality to the area.
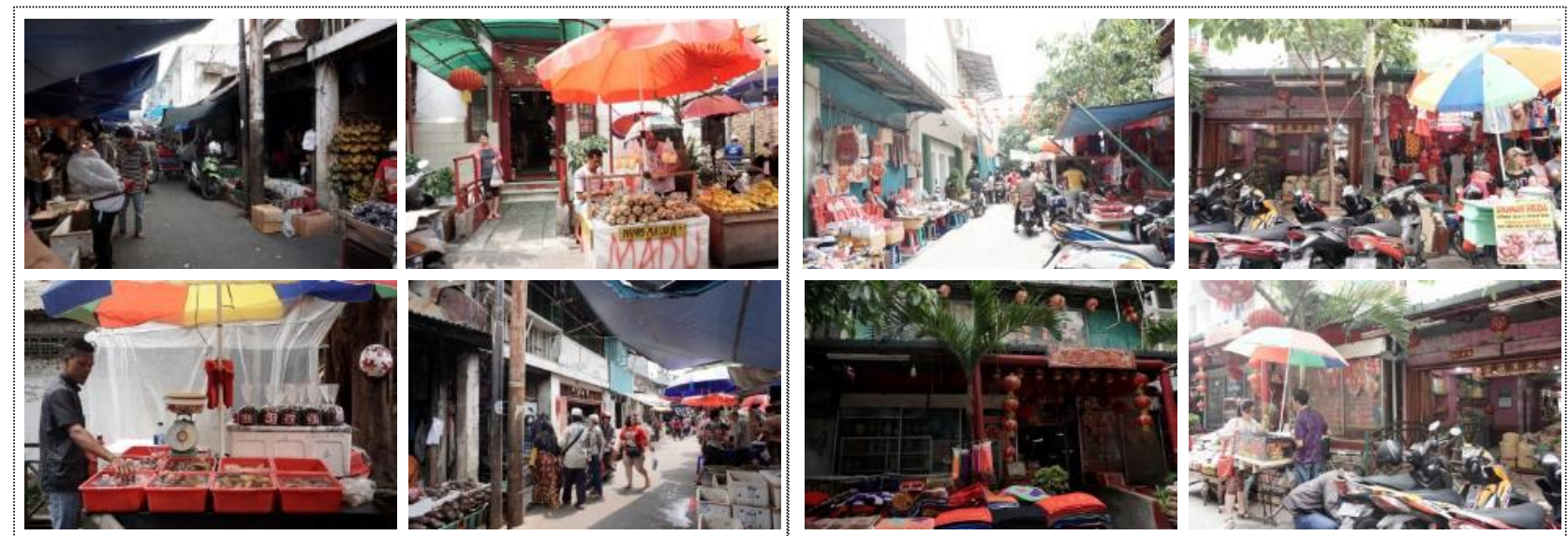

a
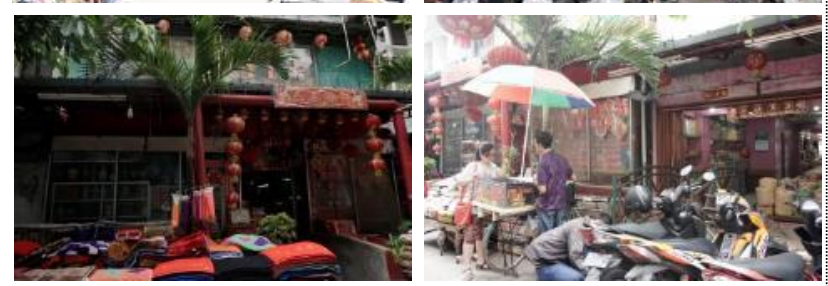

b

Figure 14. Ingredients 5 (I.5): (a). Spaces and activities related to the distribution of foodstuff;

(b). Activities and commodities related to Chinese culture

(Source: author, 2017) 


\subsection{Conclusion}

The combination of urban ingredients in the particular urban area characterizes eating out space and activities inside. The elements and the combination of urban ingredients are distinct and different from others. Urban ingredients may remain, change, transform in many variants, but we can explore the root of these ingredients within the community. It also relates to how the community uses and senses the eating space. In this case, the community has a significant role either in keeping or changing the core elements of urban ingredients. Understanding the pattern of urban ingredients of an urban area related to food and eating out activities is important because it can be the fundamental aspect of placemaking, as well as to keep the root of communities. However, how the possibilities of urban ingredients combination relate to the production of eating out space in urban spatial context need further research.

This research reveals that urban ingredients are mostly affected by the changing of community. It also relates to the meaning of eating out activities. Furthermore, how food occupied space can also be seen by the type of eating out space. At the times when Jalan Pancoran mostly visited by European elite community, the activities of eating out reflected social status in the concept of the restaurant. Chinese Indonesian community as the restaurant owner and the European community played an important role in characterizing the eating out activities as the main activities in this strip. Nowadays, eating out activities emerge in various forms, namely restaurant, coffee shop, Kopitiam, kiosk, street vendors and market in urban spatial context. In this case, the meaning of eating out activities changes from reflecting social status to revealing the identity, recalling the memory, getting specific eating experience, as well as fulfilling the basic need. Some urban elements, such as religion, people, commercial as main activities, traditional market and the existence of urban food legend become the most influential urban ingredients. They build character and give the domino effect on the food-related activities and space of eating in this area. Figure 3 shows the relation of community, eating out activities, eating out space and the urban ingredients of Pancoran, Petak Sembilan, Gloria and Kalimati Alleys, West Jakarta.

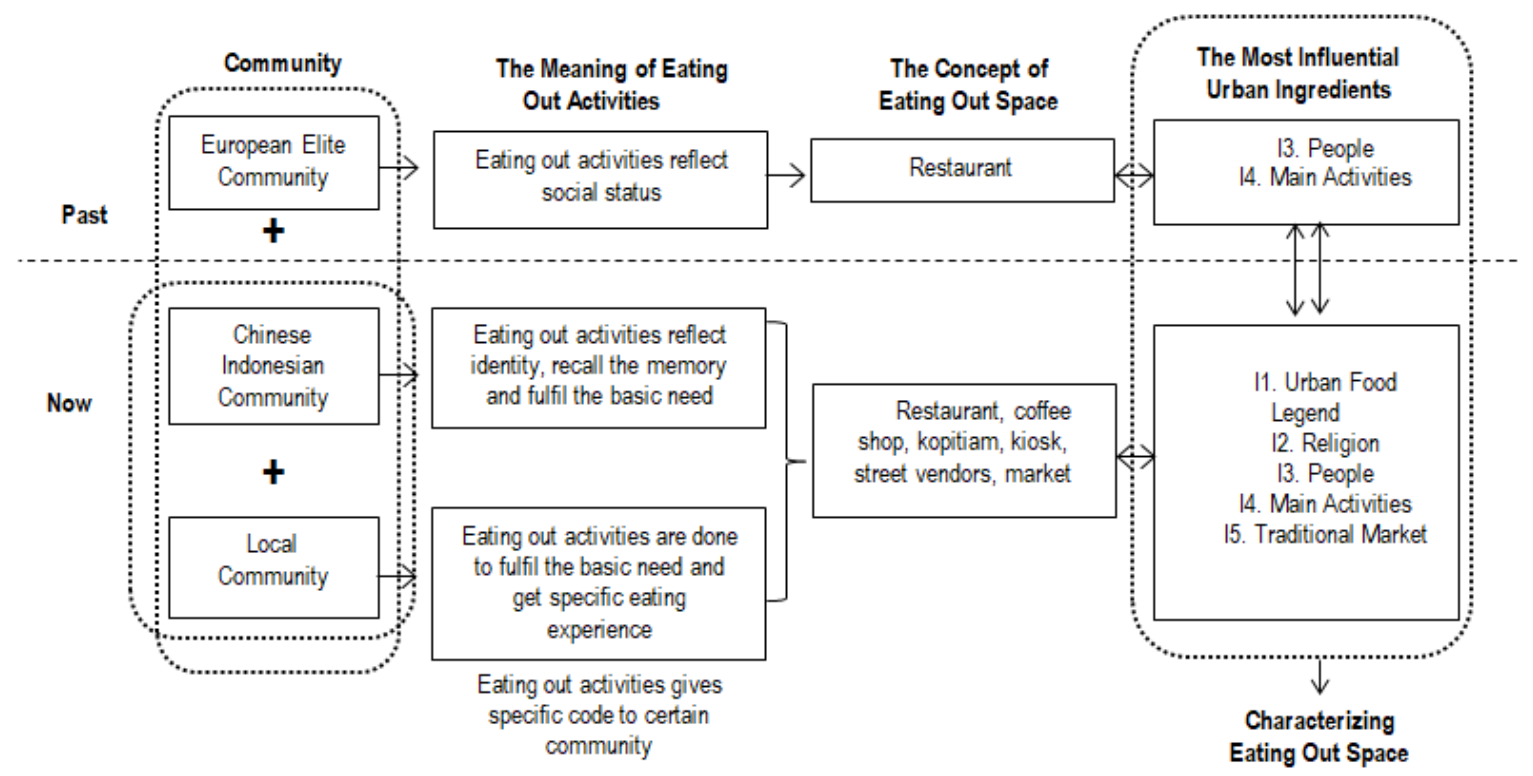

Diagram 3. The relation of community, eating out activities, eating out space and the urban ingredients of Pancoran, Petak Sembilan, Gloria and Kalimati Alleys

(Source: author, 2017)

\section{Acknowledgements}

This paper is a part of Olga Nauli Komala's doctoral dissertation in the initial stage and as a continuation of previous research which we presented at Humboldt Kolleg in July 2017. Ministry of Research, Technology and Higher Education of the Republic of Indonesia is funding our research under Applied Research of Higher Education/ Penelitian Terapan Unggulan Perguruan Tinggi (PTUPT) 2017 with contract number: 2741/UN2.R3.1/HKP05.00/2017. We would like to express our gratitude to all who have contributed to this paper, especially the residents and food sellers of Pancoran, Petak Sembilan, Gloria and Kalimati Alleys, West Jakarta, and all colleagues in the Department of Architecture, Faculty of Engineering, University of Indonesia.

\section{References}

Ariffin, H.F., Bibon, M.F., Abdullah, R.P.S. (2017). Restaurant's Atmospheric Elements: What Customer Wants. Journal of ASIAN Behavioural Studies, 2(3), Jun.85-94 
Basri, N.H., Ahmad, R., Anuar, F.I., Ismail, K.A. (2016). Effect of Word of Mouth Communication on Consumer Purchase Decision: Malay Upscale Restaurant. Procedia - Social and Behavioral Sciences, 222, $324-331$

Brown, Yasmin - Alibhai (2003). Café Societies. AA Files, No. 49 (Spring 2003), 35 - 39. Architectural Association School of Architecture, http://www.jstor.org/stable/29544747

De St. Maurice, G. (2012). Savoring Kyoto: Sensory Fieldwork on the Taste of Place. Etnofoor, 24(2), Taste (2012), pp. 106-122. Stichting Etnofoor, http://www.jstor.org/stable/43264048

Danesi, M. dan Perron, P. (1999). Analyzing Culture, An Introduction and Handbook. Bloomington: Indiana University Press

Gehl, J. (2011). Life Between Buildings, Using Public Space. Washington: Island Press

Gumerman IV, G. (1997). Food and Complex Societies. Journal of Archaeological Method and Theory, 4(2), Jun 1997, 105 - 139

Horwitz, J. dan Singley, P. (2004). Eating Architecture. Cambridge: Massachusetts Institute of Technology

Ismail, T.A.T., Muhammad, R., Yusoff, N.M., Shariff, S.M. (2016). The Myth and Reality of Hotel Brand and Food Quality: The Case of Hotel Restaurants in Malaysia. Procedia - Social and Behavioral Sciences, 222, $382-389$.

Jayne, M. (2006). Cities and Consumption. New York: Routledge

Johnston, J.; Rodney, A., dan Szabo, M. (2012). Place, Ethics and Everyday Eating: A Tale of Two Neighbourhoods. Sociology, 46(6), December 2012,1091 - 1108. Sage Publications, Ltd. http://www.jstor.org/stable/43497341

Kim, S., and Ellis, A. (2014). Noodle Production and Consumption: From Agricultural to Food Tourism in Japan. Tourism Geographies, 17:1, 151 - 167. Routledge, http://dx.doi.org/10.1080/14616688.2014.978812

Lefebvre, H (1991). The Production of Space. Massachusetts: Blackwell

Lim, C.J (2014). Food City. New York: Routledge

Lim, S. G.(2004). Identifying Foods, Identifying Selves. The Massachusetts Review, 45(3), Food Matters (Autumn, 2004), 297-305. Massachusetts Review, Inc., http://www.jstor.org/stable/25090909

Mintz, S.W., dan Du Bois, C.M. (2002). The Anthropology of Food and Eating. Annual Review of Anthropology, 31, 99 - 119. Annual Reviews, http://www.jstor.org/stable/4132873

Muhammad, R., Zahari, M.S.M., Kamaruddin, M.S.Y., Ahmat, N.C. (2013). The Alteration of Malaysian Festival Foods and Its Foodways. Procedia - Social and Behavioral Sciences, 101, $230-238$

Muhammad, R., Zahari, M.S.M., Ramly, A.S.M., Ahmad, R (2013). The Roles and Symbolism of Foods in Malay Wedding Ceremony. Procedia - Social and Behavioral Sciences, $101,268-276$

Muhammad, R., Ibrahim, M.A., Ahmad, R., Hanan, F. (2016). Psychological Factors on Food Neophobia among the Young Culinarian in Malaysia: Novel Food Preferences. Procedia - Social and Behavioral Sciences, 222, 358 - 366.

Muhammad, R., Zahari, M.S.M., Shariff, M.S.M., Abdullah, K., M. (2016). Malaysian Foodways: Acculturation/assimilation Towards Authenticity Sustainability Among Diasporic Community. Procedia - Social and Behavioral Sciences, 222, 367-373.

Neal, Z.P. (2006). Culinary Dessert, Gastronomic Oases: A Classification of US Cities. Urban Studies, Vol. 43, No. 1, 1-21, January 2006. Routledge, doi: $10.1080 / 00420980500388728$

Nor, N.M., Sharif, M.S., Zahari, M.S.M., Salleh, H.M., Isha, N., and Muhammad, R. (2012). The Transmission Modes of Malay Traditional Food Knowledge within Generations. Procedia - Social and Behavioral Sciences, $50,79-88$

Oliveira, V. (2016). Urban Morphology, An Introduction to the Study of the Physical Form of Cities. Switzerland: Springer International Publishing

Omar, D., Ibrahim, F.I., and Mohamad, N.H.N. (2017). Open Spaces and Human Interaction. Asian Journal of Behavioural Studies, Apr/ Jun 2017,37 - 46

Rahadi, R.A. (2017). Repeat Consumption Behavior in Traditional Markets: Bandung and Surrounding Regions. Journal of Asian Behavioural Studies, 2(4), 81-90

Shultz, C. (1991). Genius Loci: Towards a Phenomenology of Architecture. New York: Rizzoli

Sharif, M.S.M., Zahari, M.S.M., Nor, N.M., Muhammad, R. (2013). Factors that Restricts Young Generation to Practice Malay Traditional Festive Foods. Procedia Social and Behavioral Sciences, 101, 239-247

Stringfellow, L.; MacLaren, A.; Maclean, M.; O'Gorman, K. (2013). Conceptualizing Taste: Food, Culture, and Celebrities. Tourism Management 37, 77 - 85. Elsevier Ltd., http://dx.doi.org/10.1016/j.tourman.2012.12.016

Sutton, D.E (2010). Food and The Senses. Annual Review of Anthropology, Vol. 39 (2010), 209-223. Annual Reviews, http://www.jstor.org/stable/25735108

Teh, N.S.A., Hamid, M.R.A., Asmawi, U.M.M., Nor, N.M. (2016). Food Hygiene's Knowledge, Attitudes, and Practices between Urban and Suburban Adolescents. Procedia - Social and Behavioral Sciences, 234, 36 - 44 
Telfer, E. (1996). Food for Thought, Philosophy, and Food. New York: Routledge

Torres, J.M.M., dan De La Fuente, G.M.C. (2012). Traditional Regional Cuisine as An Element of Local Identity and Development: A Case Study From San Pedro El Saucito, Sonora, Mexico. Journal of Southwest, 54, 4 (Winter, 2012), 599- 620

Twiss, K. (2012). The Archaeology of Food and Social Diversity. Journal of Archaeological Research, 20(4), 357 - 395. Springer, http://www.jstor. Org/stable/

Ujang, N. (2017). Place Attachment and Continuity of Urban Place Identity. Asian Journal of Environment-Behaviour Studies, 2(2), 117 - 132

Voon, B.H. (2017). Service Environment of Restaurants: Finding from the Youth Customers. Journal of ASIAN Behavioural Studies, 2(2), 67-77

Wardono, P., Hibino, H., Koyama, S. (2017). Effects of Restaurant Interior Elements on Social Dining Behavior. Asian Journal of Environment-Behaviour Studies, 2(4), $43-53$.

Yusof, N.M., Ibrahim, A.A., Muhammad, R., Ismail, T.A.T. (2016). Determinants of UiTM Students' Revisit Intention to Kopitiam in Penang. Procedia - Social and Behavioral Sciences, 222, 315 - 323 